\title{
ResearchArticle
}

\section{Integrated management of bacterial wilt of ginger incited by Ralstonia solanacearum}

\author{
Roop Singh
}

\section{SUMMARY}

An experiment was conducted to find out the integrated management of Ralstonia solanacearum infecting ginger. Two antibiotics, two biocontrol agents, one phytoextract and one organic amendment and their combination were used. The average reduction in pre emergence seed rot and post emergence seedling mortality recorded with all the treatments tested were ranged from 16.50 to 80.39 per cent over untreated. However, significantly highest reduction in average preemergence seed rot and post- emergence seedling mortality was recorded with streptocycline + P. fluorescens $(80.39 \%)$. This was followed by streptocycline + karanj cake $(72.31 \%)$, streptocycline + T. viride $(69.55 \%)$, streptocycline $(58.68 \%)$, karanj cake + A. sativum $(48.49 \%)$, P. fluorescens (44.94\%), karanj cake (36.79\%). Whereas, T. viride, A. sativum and gentamycin were found least effective with comparatively minimum reduction in average mortality, 26.94, 20.94 and 16.50 per cent, respectively. Of the treatments tested, significantly highest root length $(8.60 \mathrm{~cm})$, shoot length $(18.43 \mathrm{~cm})$ and vigour index (2342.69) were recorded with streptocycline + P. fluorescens.

Key Words : Mortality, Ralstonia solanacearum, Zingiber officinale, Integrated management

How to cite this article : Singh, Roop (2020). Integrated management of bacterial wilt of ginger incited by Ralstonia solanacearum. Internat. J. Plant Sci., 15 (2): 86-91, DOI: 10.15740/HAS/IJPS/15.2/86-91, Copyright@ 2020: Hind Agri-Horticultural Society.

Article chronicle : Received : 27.04.2020; Revised : 15.05.2020; Accepted : 03.06.2020

\section{AUTHOR FOR CORRESPONDENCE}

Roop Singh, Krishi Vigyan Kendra, Karauli (Rajasthan) India

Email : roop0008@gmail.com 